Biol. Stud. 2015: 9(3-4); 23-30 • DOI: https://doi.org/10.30970/sbi.0903.450

www.http://publications.Inu.edu.ua/journals/index.php/biology

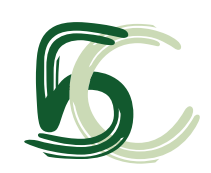

UDC 616-006.487.48-039.36-037-053.2: 575.24

\title{
SIGNIFICANCE OF miR-885-5p IN NEUROBLASTOMA OUTCOME
}

\author{
M. Inomistova ${ }^{1,2}$, N. Khranovska', O. Skachkova', G. Klymnyuk', S. Demydov ${ }^{2}$ \\ ${ }^{1}$ National Cancer Institute, 33/43, Lomonosov St., Kyiv 03022, Ukraine \\ e-mail:m.inomistova@gmail.com \\ ${ }^{2}$ Taras Shevchenko National University of Kyiv 64, Volodymyrska St., Kyiv 01601, Ukraine
}

Neuroblastoma is the most common extracranial malignant solid tumor in children. This disease displays a remarkable heterogeneity in clinical behavior, ranging from spontaneous regression to rapid progression and resistance to therapy. Recent evidence has shown that microRNAs are often involved in regulation of tumor development and progression. MiR-885-5p has a tumor suppressive role in neuroblastoma, interfering with cell cycle progression and cell survival. MiR-885-5p leads to the accumulation of p53 protein and activates p53-mediated pathway of cell cycle arrest, resulting in upregulation of its targets. We have analyzed association of miR-885-5p expression in 58 neuroblastoma tumors with different clinical characteristics and disease outcome. In tumor samples of patients with unfavorable clinical characteristics lower miR-885-5p expression levels were observed. Event-free survival analysis showed that low miR885-5p expression was tightly associated with a significantly poorer outcome than in those with high expression of miR-885-5p. In this study, evidence is presented on miR$885-5 p$ dysregulation in neuroblastoma. As follows, along with other clinical features, it can be used as an independent prognostic and possibly therapeutic approach for optimization of neuroblastoma treatment.

Keywords: neuroblastoma, miR-885-5p, prognostic marker, marker of prognosis.

\section{INTRODUCTION}

Neuroblastoma (NB) is a malignant tumor of the sympathetic nervous system reaching $11.7 \%$ of all malignancies in children and taking fourth place in structure of cancer mortality after acute leukemia, central nervous system tumors and malignant lymphomas [5]. Age distribution of the disease is heterogeneous and frequency of tumor detection decreases with age. A characteristic feature of NB is its clinical heterogeneity from localized tumors to widespread forms and early hematogenous metastasing. However, $\sim 40 \%$ of NB rapidly progress despite multimodal treatment regimens. This high clinical heterogeneity reflects a complexity of genomic abnormalities that are characterized for NB tumors [7].

Multiple segmental aberrations of chromosomes and individual gene amplification, particular MYCN oncogene, are inherent for aggressive NB. Amplification of MYCN gene is observed in $\sim 25 \%$ of primary tumors and is associated with rapid tumor progression

ISSN 1996-4536 (print) • ISSN 2311-0783 (on-line) • Біологічні Студії / Studia Biologica • 2015 • Том 9/№3-4 • C. 23-30 
and poor prognosis of the disease in patients of any age and stage. Although, status of $M Y C N$ gene is a central stratification biological marker for risk group determination, it is important to emphasize that MYCN gene amplification is not detected in most of metastatic NB [4].

Despite extensive knowledge of somatically acquired genomic rearrangements in NB and their correlation with clinical tumor phenotype, very few data are known about the factors leading to these genetic events. Inactivation of p53 tumor suppressor pathway allows cell survival during stress and occurs in many human cancers; however, normal embryonic stem cells and some cancers such as NB maintain wild-type human TP53 $[9,13]$. Recent studies demonstrate that p53 is generally functional, it accumulates in nucleus in response to DNA damage, and is efficiently degraded by MDM2 in NB. There are reports that p53 function may be compromised as a consequence of aberrant MDM2 expression levels in NB [8]. In the last years, new mechanisms of TP53 gene activity regulation have been identified, among which epigenetic factors, namely microRNA - a new class of RNA, were discovered in 1993 [11].

The occurrence of many cancers is a result of accumulation of genetic and epigenetic changes. While genetic alterations are almost impossible to reverse, epigenetic changes can dynamically respond to signals from physical, biological and social environments [3]. This characteristic confers the importance of epigenetic research in various cellular processes, particularly in gene expression regulation. New functional studies suggest that microRNAs regulate important genes involved in NB pathogenesis [10]. MicroRNA is a class of non-coding RNAs consisting of approximately 22 nucleotides, which play an important role in regulation of mRNA translation and degradation, resulting in genes suppressing. MicroRNAs are known to regulate oncogenes, tumor suppressor genes, genes involved in cell cycle regulation, cell migration, apoptosis and angiogenesis [12].

Several commonly lost genomic regions have been characterized in NB, without identification of the genes responsible for tumour suppression. 3p25.3 region is deleted in $\sim 14 \%$ of NB, and houses miR-885-5p [1]. Afanasyeva E.A. et al. [2] has provided evidence that miR-885-5p is a candidate for NB tumour suppressor and involved in directing cell phenotype of NB. Experimentally enforced expression of miR-885-5p in NB cell lines resulted in growth inhibition, senescence and apoptosis. MicroRNA miR-885$5 p$ inhibits proliferation and survival, and positively regulates p53 pathway.

The aim of our study was to analyze level of miR-885-5p expression in NB tumours and to investigate its association with clinical characteristics and disease outcome to determine a possibility of its application as a prognostic marker of NB.

\section{MATERIALS AND METHODS}

Patients. 58 patients with verified NB diagnosis have been enrolled into this study. The age of patients ranged from 1 month to 17 years. Mean age was $37.2 \pm 5.9$ months. Tumor samples were collected before any cytoreductive treatment by biopsy or tumor resection. Fresh tumor samples for qPCR analysis were stored in "RNA-later" (Ambion, USA) to stabilize RNA and DNA; for fluorescent in situ hybridization (FISH), formalin-fixed, paraffin embedded tissue (FFPE) samples were used. Written informed consent was obtained from patients' parents for tissue sampling according to the requirements of the protocol N 35 from 1.03.2015 approved by Ethical Commission of the National Cancer Institute.

ISSN 1996-4536 (print) • ISSN 2311-0783 (on-line) • Біологічні Студії / Studia Biologica • 2015 • Том 9/№3-4 • С. 23-30 
Real-time quantitative PCR (Real-time qPCR). Nucleic acids were extracted from tumor samples using silica gel-based membrane purification method (NucleoSpin MiRNA, Macherey-Nagel) according to the manufacturer's instructions. Briefly, $20 \mathrm{ng}$ of total RNA were reverse transcribed to cDNA with stem-loop primers and the TaqMan MicroRNA Reverse Transcription kit (Applied Biosystems, USA). TaqMan MicroRNAAssays (Applied Biosystems, USA) were used to quantify endogenous miR-885-5p. Data were normalized to U6 microRNA expression. Real-time RT-qPCR was performed with 7500 Real-Time PCR System (Applied Biosystems, Foster City, CA, USA) and TaqMan Universal PCR MasterMix. Calculations were performed using the $\triangle \Delta C$ t relative quantification method. The thresholds and baselines were set manually in SDS and $\mathrm{Ct}$ values were extracted.

Genomic MYCN status was assessed in NB fresh tumors by real-time qPCR analysis and FISH for FFPE samples. MDM2 expression level was detected by real-time RT-qPCR using TaqMan primers and probes (primers and probes sequences are given in [8]). MYCN status and MDM2 expression in NB tumor samples were analyzed, as previously described [8]. Results were normalized to relevant controls.

Statistical analysis. All experiments were repeated independently at least three times. Gaussian distribution of the group was checked with Kolmogorov-Smirnov tests. Analysis of the association between the studied markers and clinical characteristics of patients was performed using U-Mann-Whitney test. Prognostic significance of markers was verified with the ROC-curve (Receiver Operating Characteristic curve). Event-free survival was evaluated by Kaplan-Meier estimator, statistical significance of parameters differences was determined using F-Cox criterion. The data were processed with the software package Statistica 6.1 using parametric and nonparametric methods of statistical analysis and MedCalc 12.1.4.0. The difference was considered statistically significant at $p<0.05$.

\section{RESULTS AND DISCUSSION}

It was found that the value of miR-885-5p expression in tumor cells of patients with NB varied in a wide range. The lowest miR-885-5p expression level was established in the recurrent and metastatic tumor samples compared with primary tumors, $p=0.04$ (Fig. 1, A). This suggests that miR-885-5p is involved in progression of the disease.

Patients were subdivided by age into patients younger than 12 months, patients from 12 to 24, and patients 24 months of age and older (Fig. 1, B). Stage was dichotomized for the entire NB cohort with respect to metastatic progression (i.e., stage 1, 2, and 3 vs stage 4) (Fig. 1, C). We also defined groups with different $M Y C N$ status causing clinically aggressive NB course (Fig. 1,D). Virtually all NB have wild-type TP53 before chemotherapy treatment, suggesting that $\mathrm{p} 53$ may be attenuated by another mechanism in these tumors e.g. by its direct antagonist - MDM2 [14]. Patients were divided into 2 groups according to level of expression of MDM2 [8] (high and low) (Fig. 1, E).

The occurrence age of patient is an independent prognostic marker of NB and is used in different stratification systems. Patients older than 1 year constitute a high risk group [6]. In this study, we observed not statistically significant decrease of miR-885-5p expression depending on patients' age, $p>0.05$ (Fig. 1, E). Despite that no significant difference of miR-885-5p expression was found in tumors with different MYCN status, however statistically insignificant decrease in $\mathrm{MYCN}$-amplified samples was observed, $\mathrm{p}=0.26$ (Fig. 1, D). 

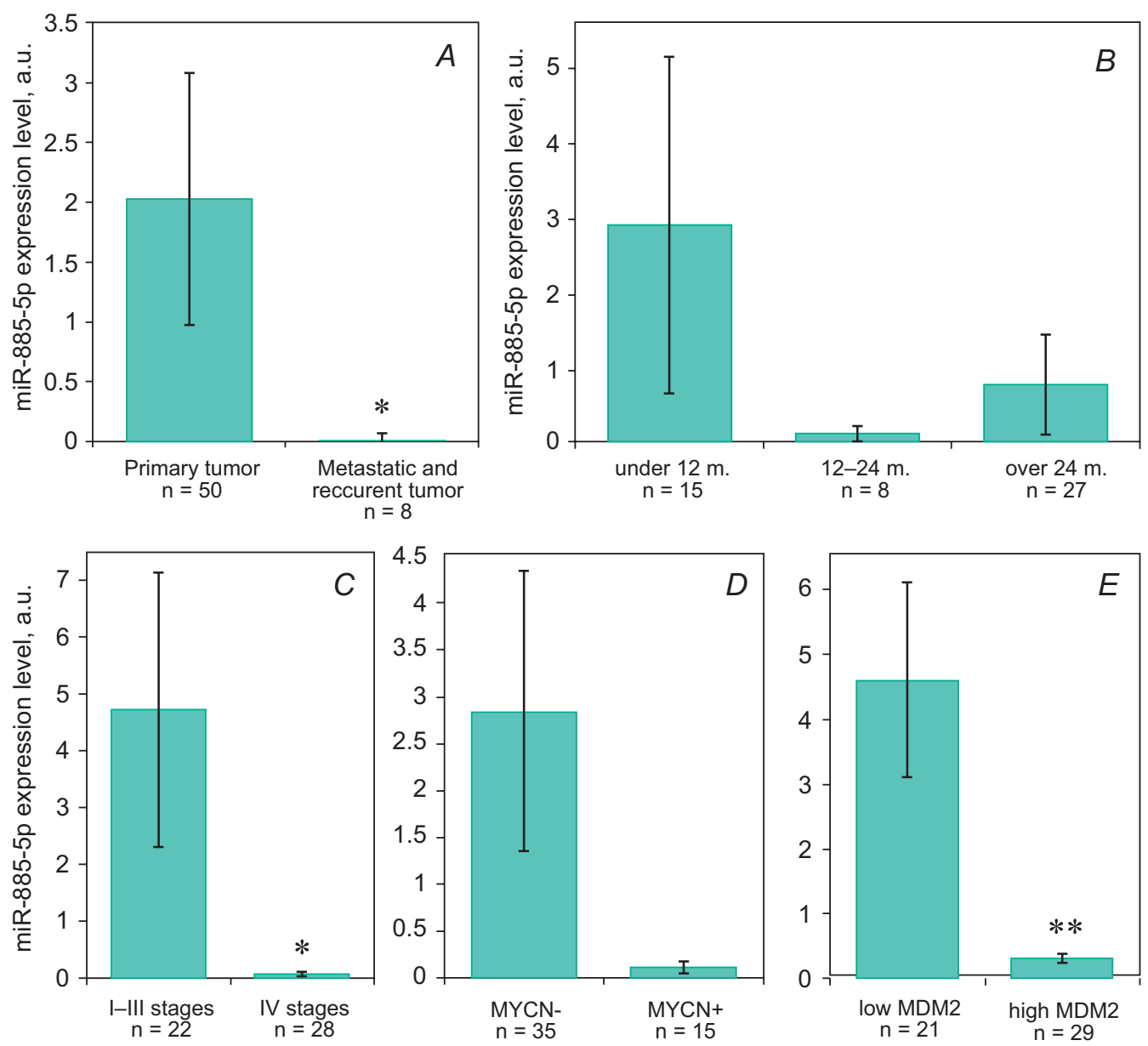

Fig. 1. Level of miR-885-5p expression in NB tumor tissue samples: $A-$ miR-885-5p expression in primary, recurrent and metastatic tumors, ${ }^{*} p=0.04$ - compared with primary tumors; $B-$ miR-885-5p expression level in primary tumors from NB patients, depending on the occurrence age; $C-\operatorname{miR}-885-5 p$ expression in primary tumors of patients with different stages of NB ${ }^{*} p=0.04$ compared with I-III stages tumors; $D$ - miR-885-5p expression level in primary tumors with and without $M Y C N$ oncogene amplification; $E-$ miR-885-5p expression in primary tumors of patients depending on the level of MDM2 expression, ${ }^{* *} p=0.02$ compared with tumors with low MDM2 expression.

Comments: m. - months, a.u. - arbitrary units

Рис. 1. Показники експресії мікроРНК-885-5р у зразках пухлинної тканини пацієнтів із нейробластомою: $A$ - показники експресії мікроРНК-885-5р у клітинах первинних, рецидивних пухлин і метастатичних вогнищ, * ${ }^{*}=0,04$ - порівняно з показниками первинних пухлин; $B$ - рівні експресії мікроРНК-885-5р у клітинах первинних пухлин пацієнтів із нейробластомою залежно від віку на момент виявлення захворювання; $C$ - показники експресії мікроРНК-885-5р у клітинах первинних пухлин пацієнтів із різними стадіями нейробластоми, * $p=0,04$ порівняно з показниками I-III стадій; $D$ - рівні експресії мікроРНК-885-5р у клітинах первинних пухлин з та без ампліфікації онкогена $M Y C N$; $E$ - показники експресії мікроРНК-885-5р у клітинах первинних пухлин пацієнтів залежно від рівня експресії MDM2, ** $\mathrm{p}=0,02$ порівняно з показниками пухлин із низьким рівнем експресії MDM2.

Примітки: m. - місяці, а.u. - умовні одиниці 
It was also found that in patients with a diffused late-stage disease miR-885-5p expression level was lower than in patients with early-stages NB, $p=0.04$ (Fig. 1, C). In addition, tumors with high MDM2 expression level had significantly lower expression of miR-885-5p, $p=0.02$ (Fig. 1, E). This testifies to theory of the important role of miR-885$5 p$ in functioning of $p 53-$ mediated pathway of cell cycle arrest.

To assess the prognostic significance of miR-885-5p expression in NB progression, $\mathrm{ROC}$-analysis was conducted. As the criterion of clinical efficacy, event-free survival rate was applied for patient distribution on groups according to miR-885-5p expression level. According to ROC-analysis, low miR-885-5p expression was shown as a marker of unfavorable NB and risk of disease recurrence. This marker had sufficient sensitivity and specificity (AUC: 0.69, $p=0.01$, Se: $89.7 \%$, Sp: $42.9 \%$, optimal criterion: $\leq 0.0713$ a.u.), and may serve as an independent marker of prognosis and stratification of NB patients on risk groups.

Patients were divided into 2 groups according to miR-885-5p expression level (high $>0.0713$ a.u. and low $\leq 0.0713$ a.u. expression level) and the event-free survival of this groups was analyzed (Fig. 2). As the result, miR-885-5p was under-expressed in $74 \%$ of patients. We found that reduced miR-885-5p level was associated with a significant decrease in event-free survival of NB patients, $p=0.02$. Accordingly, the rate of 5-year event-free survival of patients with a reduced miR-885-5p expression was 5.6 times lower than in high expression group (9.3 and $63.6 \%$, respectively). Therefore, a decreased miR-885-5p expression is associated with risk of the disease recurrence. Such a significant difference suggests that this marker has a substantial role in the pathogenesis and progression of NB.

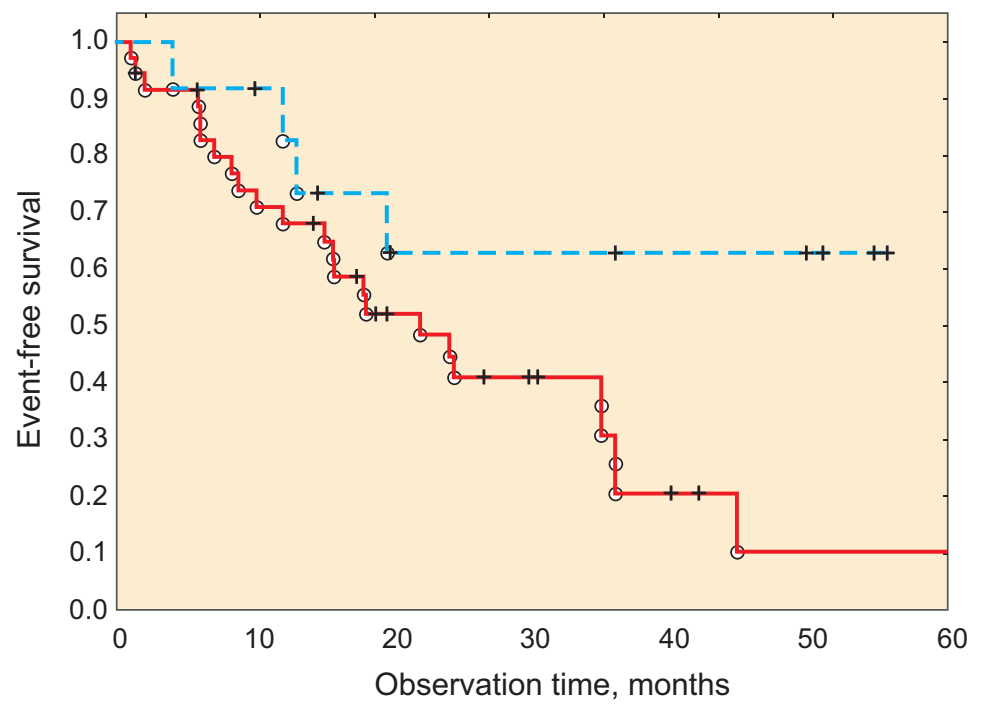

Fig. 2. Kaplan-Meier event-free survival curves according to miR-885-5p expression level in primary NB tumors $(p=0.02)$

Comments: low miR-885-5p expression level ( $\leq 0.0713$ a.u.); high miR-885-5p expression level (>0.0713 a.u.)

Рис. 1. Криві безрецидивної виживаності Каплан-Майєра відповідно до рівня експресії мікроРНК-8855 у первинних пухлинах нейробластоми $(p=0,02)$

Примітки: низький рівень експресії мікроРНК-885-5p ( $\leq 0,0713$ у.о.); високий рівень експресії мікроРНК-885-5p (>0,0713 у.о.)

ISSN 1996-4536 (print) • ISSN 2311-0783 (on-line) • Біологічні Студії / Studia Biologica • 2015 • Том 9/№3-4 • С. 23-30 
Thus, miR-885-5p is NB tumor suppressor. Along with other clinical features, it can be used as a prognostic marker and potential therapeutic approach for optimization of NB treatment.

\section{CONCLUSIONS}

The obtained results are promising for further miR-885-5p evaluation as a prognostic marker of NB progression. Modulation of miR-885-5p expression may provide novel therapeutic opportunities for improvement of NB treatment. After conducting similar studies of larger patients' cohort, this marker can be recommended for inclusion as the molecular genetic component of NB risk group stratification.

1. Afanasyeva E.A., Hotz-Wagenblatt A., Glatting K.H. et al. New miRNAs cloned from neuroblastoma. BMC Genomics, 2008; 9(52): 1-17.

2. Afanasyeva E.A., Mestdagh P., Kumps C. et al. MicroRNA miR-885-5p targets CDK2 and MCM5, activates p53 and inhibits proliferation and survival. Cell Death and Differentiation, 2011; 18(6): 974-984.

3. Bollati V., Baccarelli A. Environmental epigenetics. Heredity, 2010; 105(1): 105-112.

4. Brodeur G.M. Seeger R.C., Schwab M. et al. Amplification of n-Myc in untreated human neuroblastomas correlates with advanced disease stage. Science, 1984; 224(4653): 1121-1124.

5. Capasso M., Diskin S. Genetics and genomics of neuroblastoma. Pasche B. (Ed.) Cancer Genetics, Cancer Treatment and Research. Springer Science LLC, 2010: 65-84.

6. Evans A.E., D'Angio G.J. Age at Diagnosis and Prognosis in Children With Neuroblastoma. Journal of Clinical Oncology, 2005; 23(27): 6443-6444.

7. Gurney J.G., Severson R.K., Davis S. et al. Incidence of cancer in children in the United States. Sex-, race-, and 1-year age-specific rates by histologic type. Cancer, 1995; 75(8): 2186-2195.

8. Inomistova M.V., Svergun N.M., Khranovska N.M. et al. Prognostic significance of MDM2 gene expression in childhood neuroblastoma. Experimental Oncology, 2015; 37(2): 111-115.

9. Khranovska N.M., Inomistova M.V., Svergun N.M. et al. The role of alteration of p53/MDM2 pathway regulation in neuroblastoma progression. Clinical Oncology, 2014; 4(16): 18-21. (In Ukrainian).

10. Khranovska N.M., Inomistova M.V., Klymnyuk G.I. Role of miRNAs in neuroblastoma pathogenesis (review). Clinical Oncology, 2013; 1(9): 145-148.

11. Lee R.C., Feinbaum R.L., Ambros V. The C. elegans heterochronic gene lin-4 encodes small RNAs with antisense complementarity to lin-14. Cell, 1993; 75(5): 843-854.

12. Lu J., Getz G., Miska E.A. et al. MicroRNA expression profiles classify human cancers. Nature, 2005; 435(7043): 834-838.

13. Tweddle, D.A. Pearson A.D., Haber M. et al. The p53 pathway and its inactivation in neuroblastoma. Cancer Lett, 2003; 197: 93-98.

14. Tweddle D.A., Malcolm A.J., Bown N. et al. Evidence for the development of p53 mutations after cytotoxic therapy in a neuroblastoma cell line. Cancer Research, 2001; 61: 8-13.

ISSN 1996-4536 (print) • ISSN 2311-0783 (on-line) • Біологічні Студії / Studia Biologica • 2015 • Том 9/№3-4 • С. 23-30 


\title{
ЗНАЧЕННЯ МіКРОРНК-885-5р У ПЕРЕБГГУ НЕЙРОБЛАСТОМИ
}

\author{
М. Іномістова ${ }^{1,2}$, Н. Храновська ${ }^{1}$, О. Скачкова ${ }^{1}$, Г. Климнюк ${ }^{1}$, С. Демидов ${ }^{2}$ \\ ${ }^{1}$ Національний інститут раку, вул. Ломоносова, 33/43, Київ 03022, Україна \\ e-mail:m.inomistova@gmail.com \\ ${ }^{2}$ Київський національний університет імені Тараса Шевченка \\ вул. Володимирська, 64, Київ 01601, Україна
}

Нейробластома - найпоширеніша екстракраніальна солідна злоякісна пухлина дитячого віку. Це захворювання характеризують значною клінічною гетерогенністю - від спонтанної регресії до швидкого прогресування і стійкості до терапії. Нещодавними дослідженнями встановлено, що мікроРНК часто беруть участь у розвитку і прогресії пухлин. МікроРНК-885-5р відіграє онкосупресорну роль при нейробластомі, беручи участь у регуляції клітинного циклу. МікроРНК-885-5р спричиняє накопичення білка р53 й активує р53-опосередкований шлях зупинки клітинного циклу в результаті активації його мішеней. Ми проаналізували асоціацію змін експресії мікроРНК-885-5р у 58-ми зразках пухлинної тканини нейробластоми із різними клінічними характеристиками і перебігом захворювання. У зразках пацієнтів із несприятливими клінічними характеристиками спостерігали нижчі рівні експресії мікроРНК-885-5р. Аналіз безрецидивного виживання довів, що низький рівень мікроРНК-885-5р достовірно асоційований з погіршенням перебігу захворювання порівняно з високим рівнем експресії мікроРНК-885-5р у пацієнтів.

У результаті цього дослідження встановлено, що при нейробластомі виникають зміни вмісту мікроРНК-885-5р. Отже, поряд з іншими клінічними характеристиками, зміна експресії мікроРНК-885-5р може слугувати незалежним прогностичним маркером. Окрім цього, стає можливим використання терапевтичного підходу до оптимізації лікування нейробластоми.

Ключові слова: нейробластома, мікроРНК-885-5p, прогностичний маркер, прогнозування перебігу захворювання.

\section{ЗНАЧЕНИЕ МИКРОРНК-885-5р В ТЕЧЕНИЕ НЕЙРОБЛАСТОМЫ}

\author{
М. Иномистова ${ }^{1,2}$, Н. Храновская ${ }^{1}$, О. Скачкова ${ }^{1}$, Г. Климнюк', С. Демидов \\ ${ }^{1}$ Национальный институт рака, ул. Ломоносова, 33/43, Киев 03022, Украина \\ e-mail:m.inomistova@gmail.com \\ ${ }^{2}$ Киевский национальный университет имени Тараса Шевченко \\ ул. Владимирская, 64, Киев 01601, Украина
}

Нейробластома - наиболее распространенная экстракраниальная солидная злокачественная опухоль детского возраста. Данное заболевание характеризуется значительной клинической гетерогенностью - от спонтанной регрессии к быстрому прогрессированию и устойчивости к терапии. Последние исследования показали, что микроРНК нередко участвуют в развитии и прогрессии опухолей. МикроРНК885-5р играет онкосупрессорную роль при нейробластоме, участвуя в регуляции клеточного цикла. МикроРНК-885-5р вызывает накопление белка р53 и активирует р53-опосредованный путь остановки клеточного цикла в результате активации его

ISSN 1996-4536 (print) • ISSN 2311-0783 (on-line) • Біологічні Студії / Studia Biologica • 2015 • Том 9/№3-4 • С. 23-30 
мишеней. Мы проанализировали ассоциацию изменений экспрессии микроРНК885-5р в 58-ми образцах опухолей нейробластомы с различными клиническими характеристиками и течением заболевания. В образцах пациентов с неблагоприятными клиническими характеристиками наблюдали более низкие уровни экспрессии микроРНК-885-5р. Анализ безрецидивной выживаемости показал, что низкий уровень микроРНК-885-5р достоверно ассоциирован с ухудшением течения заболевания по сравнению с высоким уровнем експрессии микроРНК-885-5p у пациентов.

В этом исследовании установлено, что при нейробластоме возникают изменения содержания микроРНК-885-5р. Таким образом, наряду с другими клиническими характеристиками, изменение экспрессии микроРНК-885-5р может служить независимым прогностическим маркером. Кроме того, становится возможным использование терапевтического подхода к оптимизации лечения нейробластомы.

Ключевые слова: нейробластома, микроРНК-885-5р, прогностический маркер, прогнозирование течения заболевания.

Одержано: 09.11.2015

ISSN 1996-4536 (print) • ISSN 2311-0783 (on-line) • Біологічні Студії / Studia Biologica • 2015 • Том 9/№3-4 • С. 23-30 